Пучкова C. I.,

s.i.puchkova@opu.ua, ORCID ID:0000-0003-4962-3885,

к.е.н., дои., доцент кафедри підприємництвва і торгівлі, Одеський національний політехнічний універcuтет, м. Одеса

\title{
РЕКРУТИНГ У ТОРГОВЕЛЬНІЙ СФЕРІ: ТЕНДЕНЦІЇ ТА КЛЮЧОВІ ПІДХОДИ
}

\begin{abstract}
Анотація. У статті визначено та досліджено актуальні тенденції, які визначають підходи до рекрутингу в торговельній сфері. Визначено основні тренди розвитку сфери торгівлі та зазначено їх взаємозв'язок із системою управління персоналом. Виділено три основні групи торговельних підприємств залежно від методів управління персоналом. Розкрито особливості управління персоналом на торговельних підприємствах певної групи. Підбір персоналу є одним із важливіших завдань для забезпечення виконання функцій і трудових операцій на торговельних підприємствах. Наведено порівняльну характеристику внутрішніх $і$ зовнішніх джерел набору персоналу. Зазначено про рекрутинг як найбільи дієвий спосіб підбору персоналу із зовнішніх джерел. Наведено визначення поняття "рекрутинг” з точки зору широкого і вузького підходів. Проаналізовано тенденції, які впливають на функцію рекрутингу, а саме: ситуація на ринку праці, специифіка роботи з кандидатами різних поколінь, правила залучення талантів, бренд роботодавия, інформачійне забезпечення та діджиталізація рекрутингу. У ході дослідження встановлено: 1. Попит на працівників у сфері торгівлі постійно зростає. Найбільша кількість вакансій належать компаніям, які торгують продуктами харчування, далі розташовуються одяг і електроніка. 2. Торгівля увійшла в топ-3 галузей, де хотіли би працювати представники всіх поколінь. Найбільше в сфері торгівлі хочуть працювати мілленіали. 3. Загострюється конкуренція за таланти, щзо вимагає змін у способах їх залучення. 4. Результативність рекрутингу залежсть від бренда роботодавия. 5. Соціальний рекрутинг є сучасним способом комунікації між кандидатом і рекрутером. б. Цифрові технології дозволяють автоматизувати скрінінг $і$ процес найму працівників. За результатами проведеного дослідження запропоновано ключові підходи до формування системи рекрутингу в торговельній сфері.
\end{abstract}

Ключові слова: рекрутинг, торговельна сфера, ринок праці, залучення талантів, соціальний рекрутинг, бренд роботодавця, реферальна програма.

Puchkova S. I.,

s.i.puchkova@opu.ua, ORCID ID:0000-0003-4962-3885,

Ph.D., Associate Professor, Associate Professor of the Department of Entrepreneurship and Trade, Odessa National Polytechnic University, Odessa

\section{RECRUITMENT IN THE TRADE SPHERE: TRENDS AND KEY APPROACHES}

\begin{abstract}
The article identified and researched current trends that determine approaches to recruitment in the trade. The main trends in the development of trade have been identified and their relationship with the personnel management system indicated. There are three main groups of trading enterprises depending on the methods of personnel management. Peculiarities of personnel management at trade enterprises of a certain group are revealed. Recruitment is one of the most important tasks to ensure the performance of functions and labor operations in trading company. A comparative description of internal and external sources of recruitment is given. It is pointed on recruitment as the most effective way to recruit staff from external sources. The definition of "recruiting" in terms of broad and narrow approaches is given. Trends that affect the recruitment function are analyzed, namely: the situation on the labor market, the specifics of working with candidates of different generations, the rules for attracting talents, the brand of the employer, information support and digitalization of recruitment. The study found: 1. Demand for staff in trade is constantly growing. The largest number of vacancies belong to companies that sell food, followed by clothing and electronics. 2. Trade is among the top 3 industries where all generations would like to work. Millennials want to work the most in trade. 3. Competition for talents is intensifying, which requires changes in the ways of attracting them. 4. The effectiveness of recruitment depends on the employer brand. 5. Social recruiting is a modern way of communication between a candidate and a recruiter. 6. Digital technologies automate screening and the hiring process. According to the results of the study, key approaches to the formation of a recruitment system in the trade are proposed.
\end{abstract}

Keywords: recruitment, trade, labor market, talent attraction, social recruitment, employer brand, referral program.

JEL Classification: F 19, J44, J69, M12

DOI: https://doi.org/10.36477/2522-1205-2020-61-18 


\section{Herald of Lviv University of Trade and Economics. Economic Sciences. № 61, 2020}

Постановка проблеми. Соціально-економічні, технологічні та демографічні тенденції в Україні не можуть не викликати адекватних змін на підприємствах будь-якої сфери діяльності, в тому числі і торговельної.

Динамічність і в той же час невизначеність багатьох процесів у торговельній сфері, сучасні тенденції іiі розвитку ставлять перед підприємствами досить складне для їх нинішнього стану завдання формування висококваліфікованого, творчо мислячого і діючого персоналу, щоб не тільки гнучко реагувати на зміни, що відбуваються в зовнішньому середовищі, але i, передбачаючи їх, діяти на випередження.

Отже, на сучасному етапі розвитку українського підприємництва в торговельній сфері підвищення конкурентоспроможності і постійний розвиток можуть здійснюватися за рахунок використання ключового фактора - персоналу.

Торгівля, незважаючи на економічну кризу, залишається одним із найбільш активно зростаючих сегментів українського ринку. Такий розвиток вимагає постійного припливу персоналу. Тому перед керівниками торговельних підприємств виникають проблеми найму кваліфікованих співробітників і вибору найбільш ефективних методів підбору.

В останні роки у зв'язку з ускладненням діяльності торговельних підприємств все більше уваги в сфері управління персоналом приділяється процесу пошуку і підбору персоналу як способу підвищення ефективності роботи. Це пов'язано з тим, що відбулися зміни щодо вимог до кандидатів як до фахівців, відкрилися нові перспективи управління персоналом у торгівлі. Так, за результатами щорічного загальногалузевого дослідження кадрових політик і практик, проведеного EY People Advisory Services у 2018 році, важливість підбору персоналу продовжує підвищуватися, посівши третє місце серед пріоритетів кадрових політик (для порівняння у 2015 році - 12 місце).

Дані обставини потребують кардинальних перетворень у системі управління персоналом, iї адаптованості до сучасних умов господарювання через такий інструмент підбору персоналу, як рекрутинг.

Аналіз останніх досліджень і публікацій. Питання дослідження проблем теорії i практики управління персоналом підприємства розглядаються в роботах вітчизняних та зарубіжних авторів: М. Армстронга, Т. Базарова, О.Віханського, В. Весніна, Б. Генкіна, Г. Деслєра, А. Сгоршина, А. Кібанова, А. Колота, О. Крушельницької, Г. Осовської, В. Пономаренка, А. Шегди, С. Шекшні, Г. Щокіна, та ін.

В економічній літературі також представлені публікації авторів щодо дослідження рекрутингу, а саме: С. Іванової, С. Карташова, А. Кібанова, М. Магури, Г. Писаревської та ін.

Аналіз літератури показує, що в працях вчених створено достатне підгрунтя для дослідження підбору персоналу підприємства. Проте все ще існує достатньо питань, пов'язаних із дослідженням аспектів підбору персоналу саме в торговельній сфері. На практиці більшість існуючих моделей підбору персоналу швидко застарівають, оскільки не відповідають викликам новітніх технологій, мінливим потребам бізнесу i зростаючим можливостям кандидатів.

Загалом в Україні на сьогодні ще не набули широкого застосування найновітніші методи підбору персоналу, хоча певні спроби в цьому напрямі реалізовуються великими підприємствами i міжнародними компаніями та підприємствами за участю іноземного капіталу. Тому дослідження питання рекрутингу в торговельній сфері потребують подальшого розвитку.

Постановка завдання. Дослідження сучасних тенденцій рекрутингу та визначення ключових підходів до організації рекрутингу в торговельній сфері.

Викладення основного матеріалу дослідження. У даний час все більша кількість керівників торговельних підприємств усвідомлює, що конкурентна перевага компанії - це перш за все перевага власного персоналу над персоналом конкурентів. Тому подальший розвиток підприємств неминуче зіткнеться з необхідністю підвищення ефективності діяльності за рахунок якісних змін у підходах до підбору персоналу.

Сфера торгівлі активно і стрімко розвивається, 3'являються нові форми торгівлі, звідси і виникають проблеми, пов'язані з підбором якісних i спеціалізованих кандидатів на вакантну посаду.

Головними трендами розвитку торгівлі стали [1]:

- Клієнтський досвід (Customer Experience, CX) - сукупність вражень, які отримує клієнт під час контакту з компанією, що поставляє товар: piвень обслуговування, дизайн торговельного залу, сервісні програми тощо. Компанії активно формують і розвивають клієнтський досвід.

- Штучний інтелект, що отримає більше поширення. За прогнозами, 85\% усіх покупок найближчими роками у торгівлі відбуватимуться із застосуванням штучного інтелекту.

- Посилення свідомого вибору споживача: дедалі частіше споживачі приймають рішення щодо купівлі, враховуючи багато факторів (екологічність продукту, внесок компанії виробника у вирішення соціальних та екологічних проблем суспільства), а не лише вартість продукту.

- 3 розвитком інформаційних технологій зростають i онлайн-продажі. Глобальні онлайнпродажі товарів повсякденного попиту зростають у чотири рази швидше, ніж традиційні. Це пов'язано 3 тим, що споживачі ведуть активний спосіб життя і не хочуть витрачати час на відвідування магазинів.

- Експерти до головних тенденцій додають також d-commerce (digital commerce) - продаж товарів через соціальні мережі. Так, наприклад, компанія Tsenso розробила спеціальну програму, яка дозволяє зібрати і відстежити інформацію про зберігання продукту від ферми до столу. На основі зібраних даних розраховується показник свіжості, тобто індикатор терміну придатності в режимі реального часу. 
- Впровадження принципу омніканальності. Омніканальність допомагає клієнтам зробити процес купівлі якомога зручнішим і об'єднує електронну комерцію 3 офлайн-магазинами, а також робить можливим доступ до єдиного асортименту товарів торговельної мережі незалежно від каналу і формату продажу (гіпермаркети, супермаркети, магазини "біля дому” або е-commerce). Наприклад, “Леруа Мерлен”, яка представлена гіпермаркетами роздрібної торгівлі будівельними матеріалами, товарами для ремонту, декору та саду, втілює принцип омніканальності. Компанія має мережу магазинів, інтернет-магазин, контакт-центр, представлена в соціальних мережах, а також пропонує своїм клієнтам ряд послуг від партнерів “під одним дахом" та комунікує 3 клієнтами через імейлрозсилку та Viber.

Зазначені тенденції, безумовно, впливають на підходи до управління персоналом торговельних підприємств.

Для розуміння специфіки управління персоналом власне на торговельних підприємствах розглянемо, яким є об'єкт управління.

Залежно від методів управління персоналом можна виділити три основні групи торговельних підприємств [2, с. 267]:

1 група - малі приватні підприємства 3 кількістю працівників до 20 осіб (підгрупа а - малі торговельні підприємства 3 кількістю працівників 1 особа; підгрупа б - малі торговельні підприємства 3 кількістю працівників - 2-20 осіб);

2 група - колективні приватні підприємства 3 кількістю працівників до 100 осіб;

3 група - великі торговельні підприємства філії всеукраїнських торговельних мереж.

На торговельних підприємствах, де працює лише один працівник (підгрупа а - малі торговельні підприємства 3 кількістю працівників - 1 особа), методи управління персоналом є досить простими. Набір кадрів відбувається переважно через спільних знайомих із подальшою співбесідою власника торгового підприємства 3 претендентом на посаду продавця, i, якщо за результатами співбесіди даний претендент влаштовує власника торговельного підприємства, одразу ж відбувається інструктаж майбутнього працівника.

Певні особливості управління персоналом мають торговельні підприємства першої групи, де працюють більше як одна особа (підгрупа б - малі торговельні підприємства 3 кількістю працівників 2-20 осіб). Відповідно, головну роль в управлінні персоналом відіграє директор (він же і власник) даного торговельного підприємства. Ним же здійснюється планування потреби в персоналі, відбір, набір і добір персоналу, розвиток, профорієнтація й адаптація персоналу, навчання, оцінка трудової діяльності, визначення винагороди, забезпечення безпеки праці.

Оскільки торговельні підприємства, що відносяться до 3 групи, є філіями всеукраїнських торговельних мереж, то їхня кадрова політика формується у центральних офісах, проте певна самостійність у вирішенні кадрових питань належить дирекції філії.

Певні особливості управління персоналом на торговельних підприємствах визначають складність і великий обсяг функцій, пов'язаних із управлінням персоналом [3, с. 85-86]:

$\checkmark$ високий обсяг трудових операцій, які пов'язані з обслуговуванням покупців і вимагають прямого контакту з ними. Ці операції не піддаються механізації й автоматизації, що визначає високу частку витрат живої праці на підприємствах галузі;

$\checkmark$ необхідність наближення до покупців пунктів продажу товарів масового попиту ускладнює можливості їх концентрації, через те основу роздрібної торгової мережі складають невеликі магазини або салони з чисельністю працівників до 15 осіб. У таких магазинах істотно обмежені можливості вузького професійного i технологічного розподілу праці, що обумовлює необхідність поєднання трудових функцій між працівниками;

$\checkmark$ ефективність праці персоналу підприємств торгівлі, зайнятого обслуговуванням покупців, багато в чому залежить від інтенсивності купівельних потоків. Цей показник неоднаковий впродовж робочого дня і в окремі дні тижня, що впливає на ступінь завантаження працівників, викликає велику частку вимушених перерв у роботі. Це негативно позначається на продуктивності праці персоналу торговельного підприємства.

Для забезпечення виконання функцій і трудових операцій на торговельних підприємствах одним iз важливіших завдань $є$ підбір працівників.

Підбір персоналу - це цілеспрямована робота по залученню в компанію кандидатів, що володіють якостями і навичками, необхідними для поточних i довгострокових потреб організації. Інакше кажучи, це пошук, тестування та наймання людей, які можуть i хочуть працювати, мають потрібні роботодавцю компетенції, знання та поділяють цінності компанії [4].

Виділяють два види джерел набору персоналу: внутрішні та зовнішні. У першому випадку кадри підбираються з числа співробітників самої компаніï, у другому - за рахунок зовнішніх ресурсів. 3розуміло, що внутрішні джерела завжди обмежені, i повністю вирішити за їх допомогою кадрові проблеми неможливо.

Найбільш поширеними джерелами найму працівників є зовнішні. 3 досвіду фахівців із підбору персоналу джерела підбору персоналу можна охарактеризувати за певними показниками (табл. 1).

Найбільш дієвим способом відбору персоналу iз зовнішніх джерел $є$ рекрутинг.

Слово “рекрутинг” походить від французького слова "recruter", що в дослівному перекладі означає набирати, вербувати, наймати будь-кого на військову службу за гроші. У німецькій мові аналогом цього терміна є "recrutiering" - набір, поповнення [5]. Подібне значення це слово має і в англійській мові, в якій згодом стало вживатися, крім колишніх значень, ще й для позначення діяльності з підбору і найму співробітників в організації. 
Порівняльні показники джерел набору співробітників

\begin{tabular}{|c|c|c|}
\hline $\begin{array}{l}\text { Методи пошуку } \\
\text { персоналу }\end{array}$ & Усереднені витрати часу & Загальний час \\
\hline Через 3МI & $\begin{array}{l}\text { Оголошення в газеті публікується через 5-7 днів. Для } \\
\text { електронних 3МІ термін скорочується до дня подачі ого- } \\
\text { лошення. На обробку резюме від кандидатів і попередні } \\
\text { інтерв'ю - 5-7 днів. }\end{array}$ & 6-14 днів \\
\hline $\begin{array}{l}\text { Через друзів і } \\
\text { знайомих }\end{array}$ & $\begin{array}{l}\text { Для повноцінного опитування оточення для спілкування } \\
\text { достатньо 3-5 днів. }\end{array}$ & 3-5 днів \\
\hline $\begin{array}{l}\text { Серед випускників } \\
\text { ЗВО }\end{array}$ & $\begin{array}{l}\text { Зв'язок і взаємодія } 3 \text { працівниками відповідних служб } \\
\text { ЗВО (5-7 днів). Збір і обробка резюме - ще тиждень. }\end{array}$ & 2 тижні \\
\hline $\begin{array}{l}\text { Всередині власної } \\
\text { компанії }\end{array}$ & $\begin{array}{l}\text { Для аналізу можливих кандидатів } 3 \text { числа працівників } \\
\text { достатньо 1-2 дні. }\end{array}$ & 1-2 дні \\
\hline $\begin{array}{l}\text { Через центри } \\
\text { зайнятості }\end{array}$ & $\begin{array}{l}\text { Доведення інформації до відповідальних співробітників } \\
\text { Центрів зайнятості -7 днів. Обробка резюме шукачів - } \\
\text { 5-7 днів. }\end{array}$ & 2 тижні \\
\hline $\begin{array}{l}\text { Через безкош- товні } \\
\text { кадрові агентства }\end{array}$ & $\begin{array}{l}\text { Встановлення взаємозв'язку зі співробітниками агентств - } \\
3 \text { дні. Обробка даних - } 7 \text { днів. }\end{array}$ & 10 днів \\
\hline $\begin{array}{l}\text { Через рекрутингові } \\
\text { компанії }\end{array}$ & $\begin{array}{l}\text { Надання інформації працівникам компаній - } 1 \text { день. По- } \\
\text { шук і відбір кандидатів на посаду силами рекрутингового } \\
\text { агентства - 5-10 днів. }\end{array}$ & 1-2 тижні \\
\hline
\end{tabular}

Джерело: [4]

У західній літературі 3 менеджменту “рекрутинг” розглядається як необхідна ланка кадрового менеджменту в організації і визначається як процес залучення зацікавлених у роботі в даній організації кандидатів, найбільш придатних для посади за освітою і досвідом.

Існує декілька підходів до визначення рекрутингу [6]. Відповідно до широкого підходу рекрутинг є видом діяльності, сегментом інфраструктури ринку праці, що функціонує завдяки приватним агенціям з підбору персоналу; до вузького - технологією підбору персоналу із зовнішніх джерел шляхом активного залучення потенційних кандидатів для задоволення потреб, що використовується підприємствами та рекрутинговими агенціями.

Управління персоналом у торговельних організаціях залежить від сучасних тенденцій на ринку праці в сфері торгівлі. Розглянемо ті тенденції, які $\epsilon$ важливими перш за все для такої функції управління персоналом, як рекрутинг.

Професії у сфері торгівлі є найбільш масовими. За даними Державної служби статистики, у сфері торгівлі працює орієнтовно 21,8\% зайнятого населення.

При цьому кількість робочих місць у ритейлі постійно зростає. За даними OLX, в останньому кварталі 2018 року найактивніше роботодавці шукали фахівців для роботи у сфері торгівлі (27\% усіх вакансій).

Попит на працівників у сфері торгівлі постійно зростає. На сайті robota.ua розміщена інформація про більше ніж 10000 вакансій по всіх містах України. А резюме в третьому кварталі перевищило значення 50,5 тисяч (рис. 1).

Однак для торговельної галузі характерна така проблема, як плинність кадрів. Роботодавці постійно шукають нових співробітників, щоб замінити трудових мігрантів. Через це позиція "продавець-консультант" увійшла в топ-10 найбільш затребуваних професій у 2019 році, за даними robota.ua. У той же час сфера ритейлу є однією 3 небагатьох, де середній розмір оплати праці вище, ніж у середньому по країні - на 7,3\%.

Більшість роботодавців шукає продавцівконсультантів - 51\% вакансій саме для них. Майже $20 \%$ вакансій чекають торгових представників, $8 \%$ розраховані на касирів, а по 5\% - частка керівників магазину і мерчандайзерів.

Найбільша кількість вакансій належать компаніям, які торгують продуктами харчування, далі розташовуються одяг / мода і електроніка (табл. 2).

Вважається, що ритейл - дуже складний ринок 3 погляду підбору співробітників. Дійсно, в цій галузі непросто знайти працівників, особливо коли йдеться про масовий рекрутинг.

Однак, крім змін у сфері торгівлі, на підходи до роботи 3 персоналом торговельних підприємств впливають глобальні тенденції у сфері управління персоналом.

Сучасна робоча сила перетворилася на динамічну екосистему. $42 \%$ респондентів опитування зазначили, що їхні організації здебільшого складаються зі штатних працівників. Однак роботодавці очікують, що протягом наступних кількох років залежність від контрактних, позаштатних i гіг-працівників стрімко зросте. Різноманіття ринку праці потребує від HR-лідерів та лідерів бізнесу активної співпраці при розробці інтегрованих стратегій та програм в управлінні працівниками різних категорій та оптимізації екосистеми персоналу в цілому [9]. 


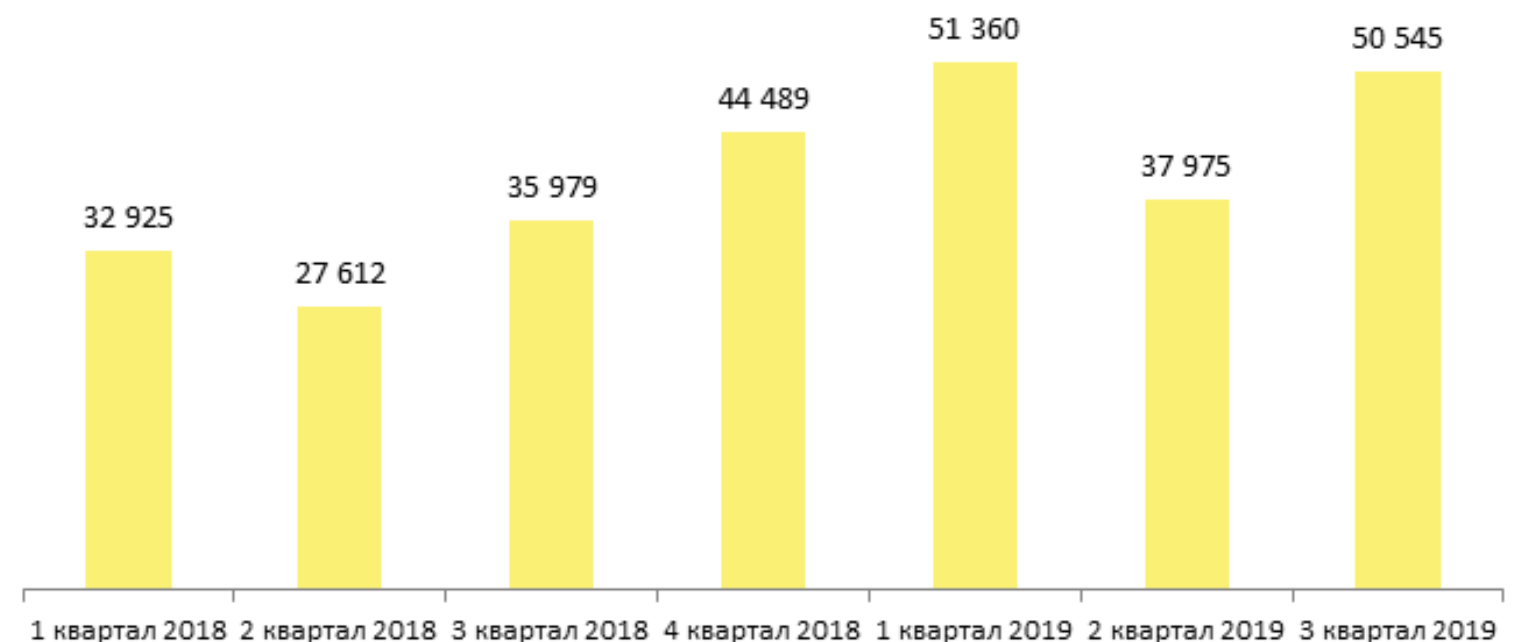

Рис. 1. Кількість нових та оновлених резюме в сфері торгівлі на сайті robota.ua в 2018-2019 p.p. Джерело: [7] поквартально

Топ-10 підгалузей компаній 3 найбільшою кількістю вакансій,

Таблиця 2 розміщених на rabota.uа в липні 2018 року

\begin{tabular}{|l|c|c|}
\hline \multicolumn{1}{|c|}{ Галузь компаній } & Підгалузь & $\begin{array}{c}\text { Кількість ва- } \\
\text { кансій }\end{array}$ \\
\hline Торгівля роздрібна / Retail & Харчові продукти & 2027 \\
\hline Торгівля роздрібна / Retail & Інше & 1397 \\
\hline Торгівля роздрібна / Retail & Одяг & 1231 \\
\hline $\begin{array}{l}\text { Торгівля гуртова /Дистрибуція / Імпорт- } \\
\text { експорт }\end{array}$ & FMCG & 1207 \\
\hline Торгівля роздрібна / Retail & Електроніка-електротехніка & 1022 \\
\hline FMСG & Харчові продукти & 759 \\
\hline Торгівля роздрібна / Retail & Гіпермаркети & 610 \\
\hline Торгівля роздрібна / Retail & $\begin{array}{c}\text { Засоби особої гігієни і побутова } \\
\text { хімія }\end{array}$ & 455 \\
\hline FМСG & $\begin{array}{c}\text { Алкогольні та } \\
\text { безалкогольні напої }\end{array}$ & 417 \\
\hline $\begin{array}{l}\text { Торгівля гуртова / Дистрибуція / Імпорт- } \\
\text { експорт }\end{array}$ & Інше & 364 \\
\hline
\end{tabular}

Джерело: [8]

В Украӥні майже 50\% компаній мають тільки традииійну робочу силу і тільки $10 \%$ організаиій розробили стратегію використання нетрадиційної праиі. На світовому рівні статистика трошки інша - 43\% і 16\% відповідно.

У 2018 році роботодавці отримали справжній виклик: навчитися ефективно управляти командами, які складаються 3 різних поколінь. На сьогоднішній день у робочому процесі компаній беруть участь представники різних поколінь: від так званих “Бебі-бумерів" (1943-1963 р. н.) і до так званого “Покоління Z" (1995-2010р. н.). Разом зі змішанням поколінь відбувається зміщення “ієрархічного віку”, при якому все частіше можна зустріти 25-річного керівника 3 підлеглими 35-55 років [10].

При проведенні у 2019 році дослідження “Формула поколінь: цінності і мотиви сучасних поколінь” було опитано 2182 відвідувачів Job-порталу та передплатників сторінок організаторів дослідження в соцмережах віком від 15-ти до 72-х років. Згідно 3 даними опитування торгівля увійшла в топ-3 галузей, де хотіли б працювати представники всіх поколінь. Попереду тільки IT і енергетика. Найбільше в сфері торгівлі хочуть працювати мілленіали. Торгівля також входить у топ-5 напрямків, із якими пов'язують або вже пов'язали свою роботу представники покоління $\mathrm{X}$ 


\section{Herald of Lviv University of Trade and Economics. Economic Sciences. № 61, 2020}

(39-53 роки). Тут кількість тих, хто пов'язаний із торгівлею, можна порівняти 3 працівниками ITсфери (по 7\%) [11].

Менеджер 3 персоналу повинен ретельно відстежувати різні нововведення в сфері підбору персоналу, щоб вчасно виправляти помилки або коригувати стратегію підбору і бути в курсі подій на ринку праці, аби своєчасно зреагувати і вжити відповідні заходи. Він може також бути і новатором ідей, пропонувати щось нове, незвичайне, нетрадиційне, тим самим відкриваючи нові методи й принципи підбору персоналу, які будуть ефективнішими та якіснішими від колишніх.

Процес рекрутингу сьогодні називають пошуком талантів, який вийшов далеко за рамки безпосередньо пошуку та найму співробітників, залучаючи всі відділи та напрямки діяльності компанії до цього процесу. Згідно з дослідженням CIPD “Resourcing and Talent Planning Survey 2017" 82\% роботодавців вважають, що конкуренція за таланти посилилася втричі за останні 5 років, і $72 \%$ респондентів очікують загострення цієї тенденції.

Прискорення цифрових, відео і когнітивних технологій і підвищення прозорості швидко змінюють способи залучення талантів (табл. 3).

До важливої тенденції рекрутингу в сфері торгівлі можна також віднести формування бренда роботодавця.

Демографічна ситуація, відтік працівників за кордон - 3 урахуванням цих факторів рекрутери мають докладати більше зусиль, щоб закривати позиції. Наприклад, в порівнянні 3 попередніми 2-3 роками трудовитрати зросли приблизно на $30 \%$. Тому так важливо починати рекрутинг із розвитку бренда роботодавця.
Бренд роботодавця - це комплекс зусиль компанії по взаємодії з існуючими та потенційними співробітниками, що робить їі привабливим місцем роботи. Іншими словами, це сукупність функціональних і психологічних вигід, які отримує співробітник, працюючи в компанії, все те, що в свідомості ваших поточних і потенційних колег з вами пов'язано. Це те, що вони відчувають і думають про вас як про місце роботи, i те, чим діляться 3 цього приводу з іншими людьми. Крім того, імідж компанії-роботодавця також формують відгуки i враження колишніх співробітників.

Згідно з дослідженням Employer Brand Research 2017 для 88\% опитаних мілленіалів важливо бути частиною компанії 3 правильними цінностями i корпоративною культурою, 87 \% прийшло в компанію через те, що їх власні цінності збігаються 3 цінностями компанії, 50\% - не готові працювати у компаніях із поганою репутацією, навіть якщо зарплатня там висока, а власне компанії з поганою репутацією платять на $10 \%$ більше за рекрутинг одного нового співробітника [13].

Невід'ємною складовою бренда роботодавця $є$ ціннісна пропозиція для співробітників (employer value proposition, EVP) - це сукупність матеріальних і нематеріальних вигід, що пропонуються співробітнику в обмін на його знання, навички, здібності і лояльність. При цьому запропоновані вигоди (атрибути) повинні становити певну цінність для цільової аудиторії: для співробітників і кандидатів. Зазвичай виділяють зовнішні атрибути EVP, спрямовані на залучення талантів у компанію, а також внутрішні, які працюють на утримання талантів всередині компанії [13].

Залучення талантів: старі і нові правила

Табличя 3

\begin{tabular}{|c|c|}
\hline Старі правила & Нові правила \\
\hline $\begin{array}{l}\text { Рекрутери використовують iнтернет- } \\
\text { інструменти для пошуку кандидатів }\end{array}$ & $\begin{array}{l}\text { Рекрутери постійно розширюють використання соціальних ме- } \\
\text { діа, в тому числі Linkedln, Twitter, Facebook, Instagram, } \\
\text { Glassdoor, Pinterest, Quora }\end{array}$ \\
\hline $\begin{array}{l}\text { Бренд роботодавця розглядається як марке- } \\
\text { тингова стратегія }\end{array}$ & $\begin{array}{l}\text { Бренд роботодавця є загальною стратегією, яка поширюється на } \\
\text { всі можливі групи кандидатів і канали }\end{array}$ \\
\hline $\begin{array}{l}\text { Рекрутери відпрацьовують рекрутинговий } \\
\text { процес }\end{array}$ & $\begin{array}{l}\text { Рекрутери взаємодіють із менеджерами в процесі пошуку, поси- } \\
\text { люючи іх мережі зв'язків, культурні можливості та критерії } \\
\text { успіху }\end{array}$ \\
\hline $\begin{array}{l}\text { Опис посади показує, що необхідно організа- } \\
\text { ції від потенційних працівників }\end{array}$ & $\begin{array}{l}\text { Опис посади фокусується на потребах кандидатів - тактика, яка } \\
\text { залучає у три рази більше високоякісних кандидатів }\end{array}$ \\
\hline $\begin{array}{l}\text { Система відстеження претендентів - єдина } \\
\text { використовувана технологія у залученні та- } \\
\text { лантів }\end{array}$ & $\begin{array}{l}\text { Компанії використовують платформи для залучення талантів, } \\
\text { які дозволяють управляти пошуком, відео-інтерв'юванням, про- } \\
\text { цесом інтерв’ювання, відносинами з кандидатами та інтеграцією } \\
\text { кандидатів }\end{array}$ \\
\hline $\begin{array}{l}\text { Процес залучення талантів побудований на } \\
\text { ефективності, продуктивності та швидкості } \\
\text { підбору, які є більш оптимальними для під- } \\
\text { приємства }\end{array}$ & $\begin{array}{l}\text { Кандидат і рекрутер - центр процесів залучення талантів, спря- } \\
\text { мованих на турботу про досвід кандидата в кожен момент про- } \\
\text { сування по процесу підбору і найму організації }\end{array}$ \\
\hline
\end{tabular}

Джерело: [12] 
72\% лідерів у сфері рекрутингу по всьому світу вважають брендинг компанії найважливішим компонентом успіху. Згідно з дослідженням провідного американського порталу з пошуку роботи Glassdoor компанії в середньому щорічно витрачають близько 130,000 доларів на створення позитивного бренда (залежно від розміру компанії сума змінюється від 6,5 тисяч до 340 тисяч доларів) [14].

У процентному співвідношенні ця сума складається з таких компонентів [14]:

- $\quad$ Реклама в пресі, 56\%.

- Онлайн-профілі компанії, 38\%.

- Профілі в соцмережах, 33\%.

- Банерна реклама, 32\%.

- Оплата агентств із брендингу роботодавця, $31 \%$.

- Реклама на радіо і ТБ, $26 \%$.

- Внутрішні проекти, 25\%

- Зовнішня реклама, $24 \%$.

- Реферальна програма для співробітників, $22 \%$

3-поміж основних процесів управління персоналом професійний добір чи не найпершим відчув вплив тенденцій інформатизації, цифровізації та мережизації економіки та суспільства, адже саме в процеси рекрутингу найшвидше втрутились інтернет-технології та соціальні мережі.

Загалом активне використання технологій інформаційного забезпечення у рекрутингу почалося приблизно з 2005 року. Саме у цей час зароджуються сайти rabota.ua та work.ua, які використовуються для пошуку персоналу й сьогодні. Головними їх перевагами $є$ можливість розміщувати вакансії безпосередньо компаніями та наявність банку резюме, де активні шукачі розміщують інформацію про себе. Але дані ресурси не охоплюють значної та не менш важливої частини - пасивних кандидатів - людей, що не шукають роботу, але за можливості згодні перейти на кращі умови. Це менеджери з підбору персоналу почали враховувати в роботі з 2010 року і саме з цього часу активно використовують соціальні мережі для пошуку [15, с. 56].

У той період зароджується таке поняття, як соціальний рекрутинг.

Соціальний рекрутинг - це стратегія пошуку кандидатів у соціальних мережах за допомогою різних інструментів. Він $є$ сучасним способом комунікації кандидата та рекрутера $[15$, с. 56].

Цифрові технології активно впроваджуються у сферу підбору персоналу: багато компаній вже використовують предиктивну аналітику, машинне навчання та штучний інтелект. Одночасно технології дозволяють автоматизувати скрінінг і процес найму працівників, а інтерв'ю проводять вже не тільки рекрутери, а й чат-боти та роботи. Вивчаючи основні тенденції переходу функції підбору персоналу в цифрове середовище, у HeadHunter Україна виділили такі ключові тенденції HR Digital [16]:

$\checkmark$ роботизація та штучний інтелект (роботи та чат-боти у рекрутингу);

$\checkmark$ автоматизація процесу підбору (відеоінтерв'ю, онлайн-тестування та системи оцінки персоналу);

$\checkmark$ HR-аналітика (Big Data, предиктивна та порівняльна аналітика);

$\checkmark$ агрегація та уберизація рекрутингу;

$\checkmark$ соціальний рекрутинг (використання соціальних мереж для пошуку персоналу).

Ці інструменти дають можливість вивести процес рекрутингу персоналу на новий рівень і забезпечити підвищення якості підбору персоналу та його ефективність.

Отже, сфера управління персоналом трансформується завдяки впровадженню інформаційних технологій та діджиталізації. Функція рекрутингу знаходиться в авангарді цих змін (табл. 4).

Дослідження сучасних тенденцій рекрутингу демонструє, що склалася певна специфіка роботи 3 кандидатами для торговельних підприємств, яку необхідно враховувати при розробці комплексної стратегії пошуку і підбору персоналу.

Порівняльний аналіз рекрутингу

Табличя 4

\begin{tabular}{|l|l|l|}
\hline \multicolumn{1}{|c|}{ Критерій } & \multicolumn{1}{|c|}{ 2015 рік } & \multicolumn{1}{c|}{2020 рік } \\
\hline Рекрутинг і HR & $\begin{array}{l}\text { Рекрутинг тісно пов’язаний із НR. } \\
\text { Фахівці з підбору кадрів входять у } \\
\text { НR-відділ }\end{array}$ & $\begin{array}{l}\text { Рекрутинг трансформувався в окрему спеціаль- } \\
\text { ність. Отримали розвиток професії сорсера, } \\
\text { ресерчера і хедхантера. }\end{array}$ \\
\hline $\begin{array}{l}\text { Спілкування 3 } \\
\text { кандидатами }\end{array}$ & $\begin{array}{l}\text { Фахівці 3 персоналу ведуть ділове } \\
\text { листування через пошту }\end{array}$ & $\begin{array}{l}\text { Рекрутери ведуть швидшу комунікацію в ме- } \\
\text { сенджерах і вільно спілкуються в соцмережах. }\end{array}$ \\
\hline Публікація вакансій & $\begin{array}{l}\text { Вакансії публікуються переважно } \\
\text { на јоб-порталах або в якості ого- } \\
\text { лошень у газетах }\end{array}$ & $\begin{array}{l}\text { Јоб-портали залишаються популярним майдан- } \\
\text { чиком для публікації вакансій. Набувають по- } \\
\text { пулярності соціальні мережі, де можна шукати } \\
\text { потрібних кандидатів. Активно використовуєть- } \\
\text { ся LіпкедІп. }\end{array}$ \\
\hline $\begin{array}{l}\text { Робота з даними } \\
\text { Технології в роботі } \\
\text { рекрутера }\end{array}$ & $\begin{array}{l}\text { Робота з паперовою документа- } \\
\text { цією. Занесення даних кандидатів і } \\
\text { ведення бази вручну }\end{array}$ & $\begin{array}{l}\text { Автоматизована робота в рекрутингових систе- } \\
\text { мах. }\end{array}$ \\
\hline $\begin{array}{l}\text { Вплив теорії } \\
\text { поколінь }\end{array}$ & $\begin{array}{l}\text { Робота перез ПК } \\
\text { і Ү }\end{array}$ & $\begin{array}{l}\text { Робота на будь-якому пристрої: ноутбук, план- } \\
\text { шет, смартфон. }\end{array}$ \\
\hline
\end{tabular}

Джерело: [17] 
Висновки i перспективи подальших досліджень у даному напрямі. В межах визначених тенденцій пропонуємо формувати систему рекрутингу в торговельній сфері за такими ключовими підходами:

1. Застосування інструментів рекрутингового маркетингу (Recruitment Marketing).

Головне призначення рекрутингового маркетингу - спостерігати за останніми тенденціями на ринку і пропонувати кращі методи підбору персоналу, які сприятимуть залученню талантів.

Рекрутингова маркетингова програма передбачає визначення цільової аудиторії та іiі портрета, проведення дослідження про те, де знайти кандидатів i як їх зацікавити, визначення формату взаємодії з потенційними кандидатами на різних етапах рекрутингу.

2. Формування і розвиток бренда роботодавия (Employer Branding, )

Коли торговельна компанія тільки виходить на ринок, для залучення потоку кращих кандидатів важливо створити сильний HR-бренд - імідж організаиії як успішного і надійного роботодавия.

Для забезпечення мотивації та утримання наявного персоналу також потрібно постійно працювати над удосконаленням бренда роботодавця.

3. Формування зовнішнього кадрового резерву (Talent pools).

Рекрутери мають формувати і розвивати актуальну базу даних релевантних кандидатів для задоволення поточних і майбутніх потреб із забезпечення кадрового складу.

4. Застосування засобів соціального рекрутингу (Social Recruiting). Соціальний рекрутинг дозволяє просувати вакансії в соціальних мережах, активно шукати потенційних кандидатів, будувати 3 ними відносини й отримувати відгуки на вакантні позиціï.

5. Розробка і впровадження реферальних програм (Employee referrals)

Реферальна програма - це структурований набір заходів, які організації використовують для пошуку фахівців через рекомендації співробітників. Натомість компанії пропонують своїм співробітникам різні види винагород.

Згідно $з$ дослідженням LinkedIn кандидати довіряють співробітникам в 3 рази більше, ніж роботодавцю, у наданні інформації про роботу в компанiï.

6. Автоматизачія рекрутингу в торговельній cфpepi (Recruitment automation tools).

Інструменти автоматизації рекрутингу - це програмне забезпечення, що використовує нові технології для спрощення підбору персоналу. Ці інструменти пропонують допомогу в пошуку та залученні кандидатів. Якщо раніше рекрутери використовували Ехсеl-таблиці і CRM-системи, то сьогодні на перший план виходять all-in-one системи, що поєднують рекрутинг i HR. Вони також оптимізують, спрощують і автоматизують процес найму, роблячи його більш швидким і ефективним.

7. Застосування технологій штучного інтелекту (Artificial Intelligence).
Торговельні підприємства, як правило, наймають персонал у великій кількості. Проведення рутинного процесу рекрутингу без втрати якості залишається одним із найактуальніших питань масового набору. Для його вирішення активно застосовуються технології штучного інтелекту у вигляді так званих чат-ботів, які можуть взаємодіяти з кандидатами, оцінювати відеоінтерв'ю та розуміти емоційний стан після проведених опитувань. Експерти стверджують, що завдяки роботамрекрутерам компанії заощаджують більше 20 робочих годин на тиждень.

Технології на основі штучного інтелекту, які здатні швидко проводити велику кількість інтерв'ю кандидатів, робити первинний скрінінг і відбирати підходящих кандидатів, необхідно активно впроваджувати у практику рекрутингу в торговельному бізнесі.

Застосування зазначених підходів доцільно розглядати 3 точки зору знаходження оптимуму між інтересами кандидата i торговельного підприємства, концентруючи увагу на розробці нових способів рекрутингу.

Перспективним напрямком досліджень $є$ інноваційні методи навчання і розвитку персоналу на торговельних підприємствах.

\section{ЛІТЕРАТУРА}

1. Зінченко А. Г. Твоє майбутнє у сфері торгівлі [Текст] / А. Г. Зінченко. - К. : Юстон, 2018. - 44 с.

2. Гут Л. В. Щодо питання проблем управління персоналом підприємств торгівлі [Текст] / Л. В. Гут, Н. М. Попович, Л. Т. Савицька // Вісник Чернівецького торговельно-економічного інституту. Економічні науки. - 2011. - Вип. 4. - С. 265-268.

3. Тельнов А. С. Особливості управління персоналом на підприємствах торгівлі в сучасних економічних умовах [Текст] / А. С. Тельнов, С. Л. Решміділова, Н. А. Стеценко // Asian Journal of Scientific and Educational Research. - 2016. - No1. (19), January - June, Vol. IX. - P. 83-89.

4. Підбір, відбір і найм персоналу - 5 ефективних методів набору співробітників у компанію [Електронний ресурс]. - Режим доступу: http://bigenergy.com.ua/fnansi/bznes-dlya-pdpri/1140pidbir-vidbir-i-najm-personalu--5-metodiv-poshukuspivrobitnikiv.html.

5. Симачкова Л. А. Рекрутмент: понятие, сущность и содержание [Текст] / Л. А. Симачкова // Вестник УлГТУ. - 2010. - №2 (50). - [Електронний pecypc]. - Режим доступу: https://cyberleninka.ru/ article/n/ rekrutment-ponyatie-suschnost-i-soderzhanie.

6. Писаревська Г. I. Організація процесу зовнішнього рекрутингу [Текст] / Г. І. Писаревська // Бізнес-інформ. - 2015. - № 2. - С. 296-301.

7. Пашкина Т. Сколько платят работникам сферы торговли, и где их с нетерпением ждут: аналитика robota.ua [Электронный ресурс] / Т. Пашкина. - Режим доступа: https://thepoint.rabota.ua/skolkoplatyat-rabotnykam-sfery-torhovly-analytyka-robotaua/. 
8. Пашкина Т. Сфера торговли: какие зарплаты предлагают товароведам, продавцам и кассирам / T. Пашкина [Электронный ресурс]. - Режим доступа: https://thepoint.rabota.ua/sfera-torhovly-kakyezarplaty-predlahayut-tovarovedam-prodavtsam-ykassyram/.

9. Тенденції у сфері управління персоналом 2018. Міжнародне дослідження Deloitte [Електронний ресурс]. - Режим доступу: https://www2.deloitte.com/ua/uk/pages/humancapital/articles/human-capital-trends-2018.html\#.

10. Огляд ринку праці і кадрів України в 2018 році [Електронний ресурс]. - Режим доступу: https://ancor.ua/press/news/oglyad-rinku-praci-ikadriv-ukrayini-v-2018-roci.

11. Симоненко К. Мілленіали більше інших хочуть працювати в торгівлі. Дослідження Академії ДТЕК i HeadHunter / К. Симоненко [Електронний ресурс]. - - Режим доступу: https://rau.ua/novyni/millenialy-dtek-headhunter/.

12. Привлечение талантов: появление когнитивного рекрутинга. Глава третья из отчета Deloitte 2017 [Электронный ресурс]. - Режим доступа: https://www.talent-management.com.ua/3191privlechenie-talantov-kognitivniy-rekruting-glavaotcheta-deloitte-2017/.

13. Антуневич В. Навіщо компаніям розвивати бренд роботодавця [Електронний ресурс]. - Режим доступу: https://eba.com.ua/companies-developemployer-brand/.

14. Леонова О. 11 стратегій для залучення талантів в 2019 [Електронний ресурс]. - Режим доступу: https://hurma.work/blog/11-strategij-dlyazaluchennya-talantiv-v-2019/.

15. Василик А. В. Використання соціальних мереж у сучасному рекрутингу України / А. В. Василик, О. В. Іщенко // Економічний простір. - 2018. - № 131. - С. 53-63 [Електронний ресурс]. - Режим доступу:

http://srd.pgasa.dp.ua:8080/bitstream/123456789/877/1 /Vasylyk.pdf.

16. Підбір персоналу в цифрову епоху: вектор змін [Електронний ресурс]. - Режим доступу: https://kiev.hh.ua/article/22316.

17. Леонова О. Як змінився рекрутинг в 2020 році [Електронний ресурс]. - Режим доступу: https://hurma.work/blog/yak-zminivsya-rekruting-v2020-roczi/.

\section{REFERENCES}

1. Zinchenko, A. H. (2018), Tvoie majbutnie u sferi torhivli [Tekst], Yuston, K., 44 s.

2. Hut, L. V. Popovych, N. M. and Savyts'ka, L. T. (2011), Schodo pytannia problem upravlinnia personalom pidpryiemstv torhivli [Tekst], Visnyk Chernivets'koho torhovel'no-ekonomichnoho instytutu. Ekonomichni nauky., vyp. 4, s. 265-268.

3. Tel'nov, A. S. Reshmidilova, S. L. and Stetsenko, N. A. (2016), Osoblyvosti upravlinnia personalom na pidpryiemstvakh torhivli $\mathrm{v}$ suchasnykh ekonomichnykh umovakh [Tekst], Asian Journal of Scientific and
Educational Research, No1. (19), January - June, vol. IX, p. 83-89.

4. Pidbir, vidbir i najm personalu - 5 efektyvnykh metodiv naboru spivrobitnykiv u kompaniiu, available at: http://bigenergy.com.ua/fnansi/ bznes-dlyapdpri/1140-pidbir-vidbir-i-najm-personalu--5-metodivposhuku-spivrobitnikiv.html.

5. Symachkova, L. A. (2010), Rekrutment: poniatye, suschnost' y soderzhanye [Tekst], Vestnyk UlHTU, №2 (50), available at: https://cyberleninka.ru/article/n/ rekrutment-ponyatiesuschnost-i-soderzhanie.

6. Pysarevs'ka, H. I. (2015), Orhanizatsiia protsesu zovnishn'oho rekrutynhu [Tekst], Biznes-inform, № 2, s. 296-301.

7. Pashkyna T. Skol'ko platiat rabotnykam sfery torhovly, y hde ykh s neterpenyem zhdut: analytyka robota.ua, available at: https://thepoint.rabota.ua/ skolko-platyat-rabotnykam-sfery-torhovly-analytykarobota-ua/.

8. Pashkyna T. Sfera torhovly: kakye zarplaty predlahaiut tovarovedam, prodavtsam y kassyram, available at: https://thepoint.rabota.ua/sfera-torhovlykakye-zarplaty-predlahayut-tovarovedam-prodavtsamy-kassyram/.

9. Tendentsii u sferi upravlinnia personalom 2018. Mizhnarodne doslidzhennia Deloitte, available at: https://www2.deloitte.com/ua/uk/pages/humancapital/articles/human-capital-trends-2018.html\#.

10. Ohliad rynku pratsi i kadriv Ukrainy v 2018 rotsi, available at: https://ancor.ua/press/news/oglyadrinku-praci-i-kadriv-ukrayini-v-2018-roci.

11. Symonenko K. Millenialy bil'she inshykh khochut' pratsiuvaty $\mathrm{v}$ torhivli. Doslidzhennia Akademii DTEK i HeadHunter, available at: https://rau.ua/novyni/millenialy-dtek-headhunter/.

12. Pryvlechenye talantov: poiavlenye kohnytyvnoho rekrutynha. Hlava tret'ia yz otcheta Deloitte 2017, available at: https://www.talent-management.com.ua/ 3191-privlechenie-talantov-kognitivniy-rekrutingglava-otcheta-deloitte-2017/.

13. Antunevych V. Navischo kompaniiam rozvyvaty brend robotodavtsia, available at: https://eba.com.ua/companies-develop-employerbrand/.

14. Leonova O. 11 stratehij dlia zaluchennia talantiv v 2019, available at: https://hurma.work/blog/11strategij-dlya-zaluchennya-talantiv-v-2019/.

15. Vasylyk, A. V. and Ischenko, O. V. (2018), Vykorystannia sotsial'nykh merezh u suchasnomu rekrutynhu Ukrainy, Ekonomichnyj prostir, № 131, s. 53-63, available at: http://srd.pgasa.dp.ua:8080/ bitstream/ 123456789/877/1/ Vasylyk.pdf.

16. Pidbir personalu $\mathrm{v}$ tsyfrovu epokhu: vektor zmin, available at: https://kiev.hh.ua/article/22316.

17. Leonova O. Yak zminyvsia rekrutynh v 2020 rotsi, available at: https://hurma.work/blog/yakzminivsya-rekruting-v-2020-roczi/.

Стаття надійила до редакиіï 15 листопада $2020 \mathrm{p}$. 